\title{
Heidegger and Leonard Cohen: "You Want It Darker"
}

\author{
Babette Babich (D)
}

check for updates

Citation: Babich, Babette. 2021. Heidegger and Leonard Cohen: "You Want It Darker". Religions 12: 488. https://doi.org/10.3390/rel12070488

Academic Editor: Elliot Wolfson

Received: 26 May 2021

Accepted: 22 June 2021

Published: 30 June 2021

Publisher's Note: MDPI stays neutral with regard to jurisdictional claims in published maps and institutional affiliations.

Copyright: (C) 2021 by the author. Licensee MDPI, Basel, Switzerland. This article is an open access article distributed under the terms and conditions of the Creative Commons Attribution (CC BY) license (https:/ / creativecommons.org/licenses/by/ $4.0 /)$.
Department of Philosophy, Lincoln Center, Fordham University, New York, NY 10023, USA; babich@fordham.edu

\begin{abstract}
This article seeks to ask the question of Leonard Cohen as a poet in terms of what Heidegger calls destitute or desperate times (dürftiger Zeit) in his Wozu Dichter ("What Are Poets For")? This question requires reflection on voice and attunement, including music and eros along with nothing less Heideggerian than the thought of death, reading Leonard Cohen on what appears to be a relation to the religious — for us? for him? for the Christ? "forsaken, almost human"—but also painfully reflexive: "we kill the flame"; a poet in dark times as we face them, together and alone.
\end{abstract}

Keywords: gnosticism; music; inauthenticity; male and female desire; deity

\section{Insiders and Outsiders: Heidegger's Attunement}

This essay raises the question of Leonard Cohen as a poet in 'dark times'. To presage my conclusion, I, of course, frame my answer in the affirmative. However, at the same time, just to the extent that I draw the phrase from Martin Heidegger's "What Are Poets For?" as he begins a lecture initially given on the 20th anniversary of Rainer Maria Rilke's death, it is important to underscore that the phrase is borrowed from another poet who will be given pride of place, as Heidegger tells us with his very first line: " ' ... and what are poets for in a destitute time?' asks Hölderlin's elegy 'Bread and Wine'” (Heidegger 1971, p. 91). Here, I mean to pose this question as a question (the parsing is Heideggerian) along with a range of questions that can be arraigned together concerning the question of Heidegger and Jewish thought. ${ }^{1}$ In this fashion, I raise the question of the relation between Heidegger and Adorno who also wrote on Friedrich Hölderlin in addition to Günther Anders who also wrote on Rilke. If Anders is underread, the same cannot be said for the conjunction of Adorno and Heidegger and a number of studies read between these prickly thinkers, one versus the other, and in the German language context, the Adorno/Heidegger relation/interaction has long been analysed. ${ }^{2}$

Indeed, as Jacob Taubes (1923-1987) underlined with respect to Adorno, the issue was a matter of outsider and insider perspectives. I have explored some of this elsewhere (Babich 2007-2008), if it should be emphasized that Taubes was no outsider, with appointments in the US between Harvard and Columbia (by contrast with the New School or Fordham as in the case of some expat academics) and, finally, the Freie Universität in Berlin. Taubes was allied, one might say, with Heidegger by marriage, having married the tragically fated Susan Taubes (1928-1969) who wrote a dissertation on Heidegger and Simone Weil, a prelude to which same dissertation insists on Heidegger as gnostic (Taubes 1954). I will need the reference to gnosticism later, but I mention the insider grouping from the outset just to the extent that from such a position (on the inside) one often imagines oneself either ignored or disadvantaged, thinking that the 'other' has the privilege one aspires to, as privileged 'other' or adversary, and overlooking (which is easy to do) one's own advantage in a more rather than less closed horizon (Babich 2017).

In Heidegger circles, there are names we count in, such as Arendt to be sure, although always involving a special pleading, and such as Jacques Derrida (this was not always so), and there are names we count out, such as Giorgio Agamben (this too was not always so). There are also excluded names that we ought by rights to include, names, to say this again, such as Anders, Hannah Arendt's first husband, as Agamben notes this, as important 
for Arendt's own reflections on love. However, very much unlike Taubes, Anders was factically an outsider, excluded, quite by contrast with his cousin, Walter Benjamin, who was celebrated by nearly all and sundry, most especially Adorno.

One cannot mention Heidegger's essay on poets, asking 'what are poets for?', without a connection with music (on Heidegger's side, as I argue this as a matter of style: Babich 2006, pp. 110-16), and the same connection holds if we raise the same question with reference to Adorno, given his approach to, criticism of, and appreciation of Heidegger's reading of poetry which always catches the voice, the breath, melos. If reading Adorno and Heidegger together on music can seem a matter of free association or metonymy, this is an error to the extent that it overlooks Adorno's dependence on phenomenology, which he read through Husserl and indeed through Heidegger.

To this same extent, Adorno's reflection on the paratactic echoes Heidegger who writes of Hölderlin in What is Called Thinking,

We call the word order of the saying paratactic in the widest sense ... For the saying speaks where there are no words, in the field between the words which the colons indicate. (Heidegger 1968, p. 186)

Adorno argues that this paratactic character captures aspects of what he (and we) call the 'new music', just as it corresponds to Hölderlin's poetry. At issue is less the call to read Heidegger as if he were Hölderlin (this is not so) than to foreground, as Adorno does, a certain musical serialism in Heidegger's philosophical text as this can help us to parse his claims and his argument. For my reading, as I speak of his style, Heidegger's language is at times explicitly musical, given the "way in which" assertions and claims, including his own, are advanced: "Way' here", meaning, as Heidegger writes, "melody, the ring and tone, which is not just a matter of how the saying sounds". (Ibid., p. 35)

At issue is the question of poetry in times of indigence or neediness, at issue is music as "way" and as "melody" and not less as lifeworld, and thus I propose to read between Heidegger and Leonard Cohen. I do not thereby claim that Adorno would concur with this, not given his own claim to interpret Hölderlin's poetry as he reserves his own reading of the paratactic to this end. ${ }^{3}$ I suspect Adorno (this was his wont) would reject the claim I make, quite in addition to any reservations about musical kinds, especially pop music, as these are both well-known and overstated and, arguably, misread in the literature.

Beyond Adorno, I draw on Anders' language of music as 'lifeworld', complete with Heideggerian resonances, as this fits Cohen. Anders was central to the intersection between phenomenology and music, and Anders' formula 'being-in-music' is sustained throughout his phenomenological sociology of music (Anders 2017). In addition, there is Derrida, usually read for his reflection on Heidegger's 'ear' and on whom (and on which) there is a very large literature. ${ }^{4}$

\section{Pop Addictions and Inauthenticity}

The constellation between Heidegger and Leonard Cohen is already one I have engaged. ${ }^{5}$ Is this because writing on popular themes and pop culture, one happens into a kind of addiction? Abandoning high for low? There may be something to that, and if so, it is true of Heidegger as well, thus his reading of Rilke. For my part, I was asked to write on Michael Oakeshott, and to talk about an English author in a Canadian context, I cited Harry Potter (both the book and the film franchise) and proceeded, as I later recognized with some alarm, that I could add a name to my list of AOCs, not merely Empedocles or Pindar but also Alan Rickman/Severus Snape.

However, I am not the only one to read Heidegger in connection with pop music, and although not about Heidegger, Simon (Critchley 2014) has written an entire book on David Bowie. I offer no contest with The Hallelujah Effect (partly about Cohen, it is mostly about Adorno, Nietzsche, Beethoven, and the ancient Greek tragic musical work, Babich [2013] 2016). Still, others write on Heidegger and jazz, particularly scholars of music education (Pio and Varkoy 2015), Heidegger and the blues (Charland 2015), and William J. Richardson wrote on Bob Dylan and Heidegger (Richardson 2010). 
My previous efforts to write on Cohen and Heidegger are tacked through Heidegger's pronouns, not scholastically, which is how he means them in his own formation, but in order to parse Cohen's reflections on the beautiful, painfully moving, painfully true Unetaneh Tokef. My reading of Cohen's song and its indebtedness to the Day of Atonement applies in the spirit of the Heideggerian Jemeinigkeit—one's own having to be "the who that we are in our uniqueness", as Heidegger reminds us that death singularizes "each one of us in its claim, at the hour, at the moment of its claim" (Babich 2014, p. 135).

Later, with respect to "You Want It Darker", we will need to reflect on the significant and lyrically arch Wechsel der Töne, that is, a shift in the voice, invented by Archilochus in antiquity, copied by Hölderlin, a cut as we may also hear it as Cohen's way of singing changes as he approaches death, quite as Socrates says to Cephalus at the start of the Republic.

Cohen's "Who by Fire" was recorded on his 1974 album New Skin for the Old Ceremony. The title tells us the Yom Kippur prayer, Unetaneh Tokef, said to date back to the 10th century. There are resonances with promises made and broken, as well as fate and destiny and the capacity to hold or to fail to hold oneself to one's word. This is Nietzsche's Kantian emphasis on contracts and their fulfilment, as I, in this earlier essay, tied this reading to Derrida's remonstration: that was then, this is now, quite as endemic to love promises. (Ibid., p. 125)

For all its pain, its lists and denumerations, I point out that this is ancient, let me count the ways poetry (ibid., p. 133). To this same extent, "Who by Fire" is not a song of death but of atonement and thus a song of life. Hence although a reflection on death and dying, it does not reflect the immediate urgency of the death that, as I write there to echo the German, each one of us must die (einen Tod muss man sterben) and which in the COVID-19 era seems to have been put paid and is now a surmountable, correctable prospect that a certain amount of hand sanitizer, masks, and due caution in the realm of social contact, aided and abetted by a plan to vaccinate the world (succeeding as I write this), could sidestep if not utterly avoid.

In his contribution to Leonard Cohen and Philosophy, Gary Shapiro catches an importantly messianic tone, if Heidegger is not the counterpoint (Shapiro 2014) engages. Instead, Shapiro foregrounds the erotic, writing on "Waiting for the Miracle" as Shapiro unpacks Cohen's 1992 album The Future, including painful or awkward reflections on male erotic sensibilities which Shapiro connects with Kairos, god of timing (Figure 1), male god, he-god, of the forelock as Nietzsche reminds us: Chance, mascot of opportunities missed, balances attempted and failed, coming up short.

A gnostic emphasis may be found in Susan Taubes, glinting through the religious that this was for her and for many still today in a world of thought in the wake not merely of Nietzsche's intensification of Hegel on the 'death of God' given the long 19th century but two world wars. Today, with COVID-19 'hysteria' capped by worldwide selfishness, justifying every restriction on one's body and that of others so that one oneself might not die, or as it is said, so that important (and invisible) others, elderly relatives one may not visit (as such concerns tend to be dressed up as a worry for the 'vulnerable'), it seems there is even less room than ever for religion or for deity, or even and only, as Heidegger invoked the word, "piety" (Frommigkeit), telling us that questioning is "the piety of thought". (Heidegger 1977, p. 35)

In a sensitive and provocative essay, Robert Bernasconi seizes the intonation and the threat behind the question/promise of Heidegger speaking to his students on translation (Bernasconi 1995, p. 303), just to the extent that we may read these meditations between Cohen's poetry and Heidegger's reflections. Given the play on pronouns, Bernasconi's reading is precise, connecting what Heidegger says, "I will tell you who you are", with Greco-German destiny.

"Who by Fire" traces kinds of death, but the who that is here Heideggerian, if one will permit the language, is the refrain: "And who shall I say is calling?" This 'who' is seemingly addressed in Cohen's "You Want It Darker", foregrounding what may otherwise be read as Heideggerian forbearance in the face of a certain and clear absence-for Cohen, 
"And who shall I say is calling?" The answer returns in "You Want It Darker", repeating challenges only to answer them: 'here I am', "hineni, hineni, I'm ready my Lord."

One may argue that it is forbearance that may be heard in Cohen's compound affirmation: it's a cold and it's a broken Hallelujah. No claims are made on Deity in "You Want It Darker", but at the same time, there is no kind of abject expectation. This prayer is a priest's prayer-Cohen does not beg or plea but speaks evenly: "let me out of the game".

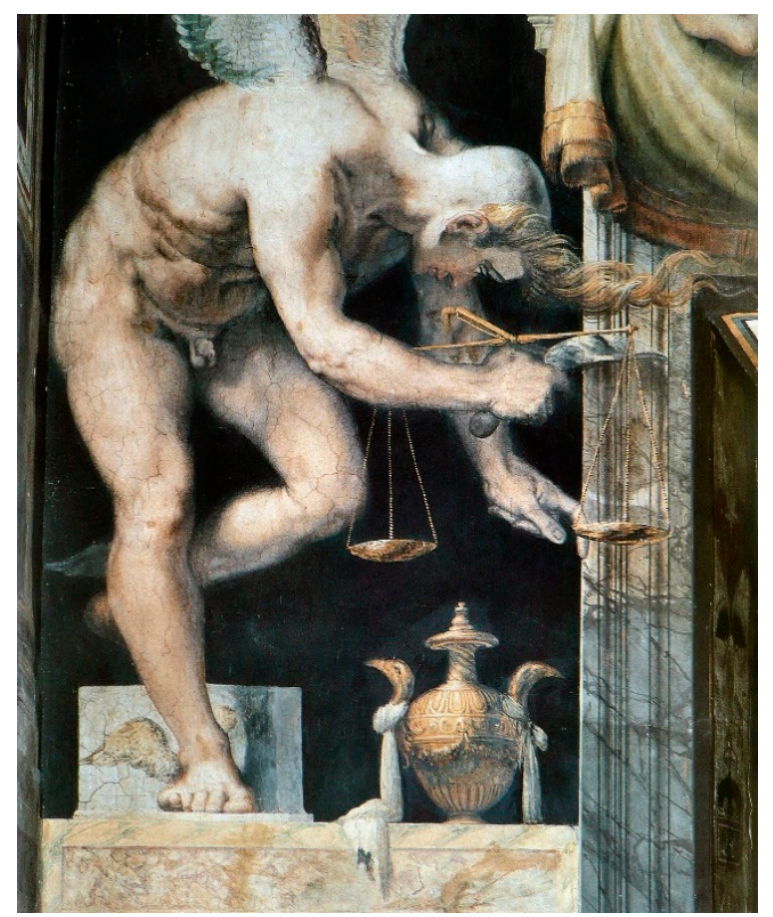

Figure 1. Francesco Salviati (Francesco de' Rossi), Kairos. 1552-1554. Palazzo Sacchetti, Rome. Public Domain. Wiki Commons.

Note that the you changes for Cohen between these songs, followed through a lifetime: the who in question is deity, as we hear the song, as the song itself becomes darker.

I read this as a Heideggerian forbearance because it is extended to deity as other, as in a priestly mode, one may claim such an address. There is also irony, as Cohen's final song plays with deity — "if you are the dealer" — adding statements of fact- "if you are the healer/I'm broken and lame" - rather than supplication. The lack of remedy is taken in stride or at least it is claimed: 'here I am', hineni, hineni. This is justice, and once again, it does not matter, "the holy or the broken".

Rebuke is not foresworn: one can cry out but not as Rilke cries, wondering, about the order of angels, their breath, and our being together-with or without the erotic, there is for Cohen "a lover in the story", undercut immediately: "but the story's still the same". Reflecting on the great depressions of his past, this is the voice of age and the voice of wisdom, "middle class and tame". This song, pace male enthusiasms, Cohen's own and others', especially his friends', is not the song of the "river-god of the blood", as we may say, post Nietzsche. Cohen's voice is sharper, clearer: "it's written in the scriptures/and it's not some idle claim". The penultimate drum beat stanza invokes incarnation—“vilified, crucified/in the human frame" - and tells us we could not be listening more closely, and the voice drops: "we kill the flame". Cohen carries his name, quite as the German would say, zu recht, rightly, justly.

\section{Being a Poet in Dark Times}

Comparisons to Hölderlin cannot but be expected to fail. One will never be able to say, as this poet said, stepping before the Judeo-Christian era to invite "Nature and Art, Saturn 
and Jupiter", to teach us the meaning of Kronion; this Jupiter is the son who dishonors his father. All that and Hölderlin says only for his needful time, his desperate indigence lasting decades, writing with calm, utterly "An die Parzen", and who else is one to address but the fates, the Norns, the furies/kindly ones? Einmal/Lebt ich, wie Götter, und mehr bedarfs nicht (Once/I lived like the gods, and more is not needed). So too, Heidegger's other favorites, such as Trakl. If Cohen may be compared to Rilke, that may not help as Heidegger's question about poets in needful times is all about Rilke's status, and the consensus is that Rilke comes up short for Heidegger, by comparison with Hölderlin.

To be fair, Cohen's poetry could arguably be esteemed above Dylan's. The Nobel Prize committee did not share that view, and when The Guardian reported the event, being unable to reach Dylan (this assures his allure), they contacted Cohen for a quote, and they were able to reach Cohen: "'To me', he said, '[the award] is like pinning a medal on Mount Everest for being the highest mountain'". Il miglior fabbro. Nothing loath, the reporter took Cohen's phrase to title the article—on Dylan (The Guardian 2016).

Overall, there are overlaps between Heidegger and Cohen: if when it comes to love Heidegger hardly compares. Günther Anders-who had reason to complain given Heidegger's affair with Hannah Arendt, his first wife, and quite in advance of their marriagewould object that sex and the body managed not to make an appearance in Being and Time; "all want", Anders would sniff contemptuously, was "wanting" (Anders 1948, p. 346; see Babich 2021a).

Anders foregrounds the erotic thread of Heideggerian concreteness (the language of reflex and intentionality is Heidegger's as we read Being and Time) as Heidegger tells us, as concretely as we might wish quite down to the word as such, that inauthenticity' in a variety of ways, Uneigentlichkeit, determines Dasein in its 'fullest concretion [Konkretion]', i.e., "when busy, when excited, when interested, when ready for enjoyment". (Heidegger [1927] 2001, p. 346).

Excitement and interest, being 'ready for enjoyment': Heidegger could not have been entirely without charm, in eroticis. His relationship with Hannah Arendt would last a lifetime, which, arguably, counts a great deal (see Maier-Katkin 2010). However, in terms of love and despite Heidegger's writing on Angst and loneliness, he is no match for Cohen as a poet. And at the level of final things, as Nietzsche writes at the start of the first volume of his Human, All too Human, I read Leonard Cohen as a poet in a time of need.

Cohen's "Hallelujah" is often commissioned as a funeral song, ${ }^{6}$ but as a eulogy, I cited Cohen's "You Want It Darker" for William J. Richardson, S.J. (1920-2016). ${ }^{7}$ One might make the case that Richardson, more than any other single scholar, brought Heidegger to an Anglophone readership. This is awkward or 'faint' praise: the achievement worked (it still works) as a kind of cheat sheet. Even those who followed Bert Dreyfus, i.e., analytic readers, would find their way to reading (if not citing) Richardson's Through Phenomenology to Thought (Richardson [1963] 2003) ${ }^{8}$, unmatched as it remained, until the simple thing that is the internet (and the growing fondness for word-frequency-style 'research'), a comprehensive take on an extensive range of Heidegger's writings, true to its title.

A eulogy gives the opportunity to praise, and faintness should have no part in that. Thus to speak to Bill's life, I told the scholars who liked him - and there were few who did not-about "You Want It Darker", recorded on the final album Leonard Cohen would issue with his son, foregrounding its Hebrew refrain hineni, hineni. I argued that the Hebrew chorus of Cohen's song summarizes the life Richardson sought to live, in Latin: ad sum. The difference would be the cantors' voice, a voice that reaches over time. ${ }^{9}$

Hebrew and Latin are critical here as Heidegger himself emphasized the importance of Greek, and in a video version of the lecture (on the Zollikon Seminars and Heidegger on the 'unfolding' of man), Cohen's song gave me an opportunity to hear a little of Cohen's words, sung by a priest by name, for a priest by profession/vocation (Babich 2019b).

If such a case anecdotally, and so metonymically, in extremis, works to connect Heidegger and Cohen in the case of "You Want It Darker", the more famous "Hallelujah" is less promising. At issue is a certain enchantment with a certain chord, the special advantage of 
David's chord-“it pleased the Lord" - and a distinctive rebuke to a particular 'you', who, awful to say, is by now said not to care, not really, for music. The theme is eros, the body that Günther Anders tells us is absent in Heidegger. It is not absent in Cohen, "Remember when I moved in you". This is all about the ecstasy of body and soul, at least for one of the lovers, although the claim is of a union, "every breath we drew was Hallelujah". One-sided or not, the distinction of unity is short-lived, "our love is not a victory march" is the key and to the point of "Hallelujah", coming and going, and either way, as emphasized: "it is a cold and it's a broken Hallelujah".

Leonard Cohen's song "Hallelujah" guarantees that it is constantly commissioned or constantly 'milked', as one commentator puts it—and still and recently, at the highest level, including 20 January 2021, for the US presidential inauguration. Thus the song is what Heidegger names Gerede, "idle talk". We do not need Adorno's or Anders' analyses of the musical culture industry and the industrial manipulation of emotion or affect, though even here a recent analysis tries to bring in Heidegger to catch the point (Anderson 2015). To be sure, the author means his argument on "Neo-Muzak and the Business of Mood" more casually than one might assume as the phrasing catches the Adorno-esque reflections of the culture industry together with what can seem a Heideggerian reflection, but allusions can be misleading, and Heidegger is a passing reference among others rather more crucial for Anderson's mainstream sensibilities. Thereby it is easy to overlook the complicating detail of Heidegger's analysis of mood as revelation (revelation of what?) along with the inherently, ineliminably levelling question of das Man, as Heidegger wonders, knocking the reader for a loop in the course of his powerfully lived, seemingly concrete, seemingly existential analysis, saying: "It could be that the 'who' of everyday Dasein just is not the 'I myself'". (Heidegger [1927] 2001, p. 115) If this takes us back to Cohen singing by the numbers in "Who by Fire?", it is plain that the 'new muzak', specifically, is the problem for such analyses and this does not merely reduce to the constant invocation of a certain song or the production of a mood on demand. Cohen's "Hallelujah" is everywhere, but it is a hymn of praise omnipresent in pop covers and recurring on television sitcoms and dramas and films, automatic soundtrack of our lives, a hymn that, should we still be listening, takes us to Cohen's promise: "I'll stand before the Lord of song, with nothing on my tongue but Hallelujah".

To be sure, the same Heidegger who cites Johann Gottfried Herder's reflection on the breath of divine creation, as effectively hovering "on our lips like a magic tone", ${ }^{10} \mathrm{can}$ remind us that in the spirit of just such inspiration, "To sing the song means to be present in what is present itself". (Heidegger 1971, p. 138) Heidegger's "poet in the time of the world's night utters the holy". (Ibid., p. 94) The trouble is considerable and challenging, and thus Susan Taubes was inclined to read her gnostic sensibility into Heidegger which she could only do in the way that Anders likewise argued: this is a theology negatived for those who, as Anders writes, are compelled to turn an absence in experience to precisely what is longed for, which is thus, as he says flatly, the allusion is to Kant, other than faith. Writing on the post-nihilist proof for the existence of deity "ex absentia", Anders characterizes Kafka, Rilke, and Beckett rather as Heidegger in "What Are Poets For?" links Rilke together with Nietzsche (Anders [1956] 1965). Thus if Heidegger finds that Rilke is not quite a poet in relict destitution, he also tells us that, and here there are echoes between Greek and German, Hebrew and Avestan (with Zoroaster), that "the creature which is Rilke's Angel, despite all difference in content, is metaphysically the same as the figure of Nietzsche's Zarathustra"' (Heidegger 1971, p. 134).

For Anders,

Here the negativity we know from "negative theology" seems to have affected the religious experience itself-thereby intensifying it immensely: while in negative theology, it was merely the absence of attributes that was being used to define God, here God's absence itself is made into a proof of His being. (Anders [1956] 1965, p. 145) 
One can argue that Anders' reading is echoed in Taubes' gnosticism, but the problem here is also a matter of nescience. Thus Anders is likely correct to write of Beckett that his is not a religious play but "ultimately only a faith that believes in itself. And that is no faith" (Ibid.). What seems clear for Heidegger's part is that he is not speaking, as Cohen is speaking, of "the Lord of song" even as all of the lines and even some of the terms would seem to match up. Thus Heidegger quotes Hölderlin as attributing to Wilhelm Heinse, author of Ardinghell and the Blessed Isles, the sentiment that also echoes in Nietzsche, darkened to be sure as the world turns into its night, describing the charge of poets in a needful era, a dark time, dürftiger Zeit:

But they are, you say, like the wine-god's holy priests,

Who fared from land to land in holy night. ${ }^{11}$

Like deity fugitives, these holy priests of the wine god-among whom Hölderlin includes the one he calls 'the Syrian' - these 'poets' move from place to place.

For Heidegger, this description characterizes the singer, such as Cohen, the poet such as Hölderlin or Rilke, should he be shown to match the task, as the line runs in the Introduction to Metaphysics, as this dates from a lecture first presented in 1935, to parallel the point Heidegger makes there, characterizing what he names, via a reading of the polis/hypsipolis in Sophocles, as

political, i.e., at the site of history, provided there be (for example) poets alone, but then really poets, priests alone, but then really priests, rulers alone, but then really rulers. $B e$, but this means: as violent men to use power, to become pre-eminent in historical being as creators, as men of action. (Heidegger 1959, p. 152)

Heidegger's reading of the first chorus from Sophocles' Antigone (lines 332-75) is rightly celebrated as a reading but also conflicted as he writes about those who are only poets [die Dichter nur], only rulers [die Herrscher nur], but then modifies only [nur] as really [wirklich] poets, really rulers (it should not fail to be noted that this was after he resigned the rectorate, which some read in terms of, if not complete, certainly already then partial fall from grace with the Nazi Party): "aber dann wirklich Dichter ... aber dann wirklich Herrscher ..." It is also a stock metaphysical point: the parallel matches Plato on seeming in the Republic as Heidegger here writes on Parmenides on Being (and seeming). Thus in "What Are Poets For?" we are told that poets "are the mortals who, singing earnestly of the wine-god", (never forget Hölderlin, as Heidegger reads Bread and Wine),

sense the trace of the fugitive gods, stay on the gods' tracks, and so trace for their kindred mortals the way toward the turning. The ether, however, in which alone the gods are gods, is their godhead. The element of this ether, that within which even the godhead itself is still present, is the holy. The element of the ether for the coming of the fugitive gods, the holy, is the track of the fugitive gods. (Heidegger 1971, p. 94)

For Heidegger, "a poet in a destitute time" attends in a time of lack, abandonedCohen's "broken and lame" —and thus the poet sings "to the trace of the fugitive gods. This is why the poet in the time of the world's night utters the holy. This is why, in Holderlin's language, the night is the holy night" (Ibid.).

Sure, for Hölderlin; but for us today, we remember that this is Nietzsche's problem, this is, as Anders tells us, Rilke's problem, "the holy is lost".

The hearing of the secret chord ties in, as the incipit, the first line of Cohen's poem, Cohen's song, with the sacred imperative 'to hear', that is, the Schma Jisrael that is not said, not intoned, not heard but which nonetheless echoes throughout "Hallelujah". Conscious of reproof - "You say I took the name in vain" — and mixed with doubt_-"maybe there's a God above" - and causal mockery - "some pilgrim who claims to have seen the light"Cohen's jokes have to be taken in stride.

If theologians and philosophers argue beginning with Hesiod's genealogy of the gods, his Theogony, and with Plato on the connection between the erotic and the divine, Cohen takes this dynamic over the top-this is his song: 


\section{But remember when I moved in you}

and the holy dove was moving too.

And every breath we drew was Hallelujah.

Elsewhere I argue that this line discomfits some performers, which means that some singers are led to cut it completely, challenging as it is for women singers. However, in The Hallelujah Effect, I suggest that k.d. lang can sing the song quite as a matter of voice.

The erotic tone is highlighted in connection with faith and its own love tests, naming "a secret chord that David played" so that we know that he, David, is the "you" addressed:

Your faith was strong but you needed proof

You saw her bathing on the roof

Her beauty and the moonlight overthrew ya.

Cohen's words seem to function in several ways, rebuking one's own heart as much as a lover:

Baby, I've been here before

I know this room, I've walked this floor

I used to live alone before I knew ya.

Thus what Cohen says about "Hallelujah", he says about love, either way, worldly and divine, cold and broken. ${ }^{12}$ Here Cohen seems to allude to Goethe-and, in any case, he makes the same point Goethe makes when it comes to love:

But if I did, well really, what's it to you?

There's a blaze of light in every word

It doesn't matter which you heard

The holy or the broken Hallelujah.

If "Hallelujah" is a David song, David, himself a singer, with his lyre, with his harp, is a king. The love song, the eros comes in the Davidic line; here I think of my first husband, Bill Strongin, now a rabbi, who first explained the relevance of music and love for David, this conflicted king. Cohen sings the same complexity to be sure. However, in "Suzanne", all bets are off, almost. The complicated comprehension of Jesus, beautifully articulated in the verse turns of "Suzanne" is not without Cohen's gentle misogyny (almost every woman who writes about him forgives him): eros, allure, abandonment.

However, all this (and this is part of the reason I read Heidegger and Cohen for the sake of a reflection on Heidegger and the Jewish tradition) may be heard in "You Want It Darker".

The early beauty of "Suzanne", enmeshing the listener in reverie, is a song for a Jew born and raised in Montreal, including the conceit that all the loci in the song are known to the listener, even one who knows other harbors, other sailors, other teas, other erotic tastes. What did Heidegger offer Arendt? What is a nice Jew, as the saying goes, doing with Heidegger?

Debra Bergoffen joked that a related question should inspire a collection put together on Nietzsche and the Jews, not that there is any shortage of such collections. I heard Debra's question as we put together the volume, ${ }^{13}$ and there it stands, as a leitmotif, as Bergoffen raises and plays with the question as she puts it, of a "Landsman-someone they can talk to. Argue with and return to again and again and again" (Bergoffen 2007-2008, p. 3). The same language perhaps might be brought to Arendt whose best and most telling answer was, when interviewed later in life on what if anything she misses in exile, as she replied with automatic conviction, Naja, and with a certain impatience: die Muttersprache. Many have taken up the challenge of engaging the question of Arendt and Heidegger (Maier-Katkin 2010 first in rank), and the theme of Heidegger and Arendt can command its own complex range of readings. 
Here, I am only reading the Heidegger who writes on poetry along with Leonard Cohen. This is where we have trouble. Cohen is a popular artist, famous for his songs quite as hits, and that already puts him somewhat to the side of what Heidegger names a poet in a destitute era, no resources: nothing. The bar seems awfully high. If Heidegger spends most of his essay reading and simultaneously, seemingly, excluding Rilke, he seemingly means to include only Hölderlin. However, to know the name of such poets, as Cohen says to refuse the charge of blasphemy by sublation-"I don't even know the name"-is this not what we need Heidegger for? Even Anders who otherwise criticizes Heidegger with all the best reasons in the world, reads Beckett and, arguably, even Kafka with and through Heidegger: as poets in 'dürftiger Zeit'. (Anders [1956] 1965)

Cohen's lyrics work, as Anne Carson argues in Eros, the Bittersweet (Carson 1986) that lyric poems work from their earliest inception, with words. Specifically, Cohen uses pronouns, and thus the listener is invited in: "Suzanne takes you down". It is her place after all: no mess, no fuss for you but, ah, the location: "You can hear the boats go by, you can spend the night forever". Madness, hers, not the poet's, not the listener's, rides the song like a wave. This is eros, as Socrates says, arbiter of divine madness, but this is hardly Cohen's poet's confession, which he shares with 'you' along with 'your' desire:

And you know that she will trust you

For you've touched her perfect body with your mind.

It is all about "you", pronouns once again, as the next line tells you, lightly, where it is suddenly plain and painfully clear that this night's travelling is the dark night of the soul, related to you but now the relation is not to a singular "her" but a singular "him", and we hear that the shift is perfect, "And Jesus was a sailor when he walked upon the water". What follows is indulgent if complex-"only drowning men could see him"—giving us a lesson in theology, between the harbor and Golgotha:

But he himself was broken, long before the sky would open

Forsaken, almost human, he sank beneath your wisdom like a stone.

The song continues to track a complex dynamic between deity and the erotic, and as I seek to argue, listening to Nina Simone, by the time Cohen's permutation of his pronouns have advanced, the singer can seem to echo Heidegger's insight into the ancient goddess of truth herself, Aletheia, tacked between the marvels of perspective, and we remember, as Lacan tells us, as Nietzsche has told us, that truth rises naked from the depths, as the ancients depict her, with a mirror in her hand.

An apparent contract with deity seems to run throughout Cohen's work-he gives an interview with Arthur Kurzweil in 1993, one extra answer to everybody's question, the interview is published under his byline, his word, his verse: "I Am the Little Jew Who Wrote the Bible" (Cohen 1993b) ${ }^{14}$ —even, to push the claim, in so patently worldly a hymn to the jet-setting world of the music profession: "First We Take Manhattan". The pronouns continue to guide us, now in the first-person plural, but who makes up, who composes the "we" in question? Does it speak for Cohen himself, speaking in the first line, in the first person, vis-à-vis the third person plural: "They sentenced me to 20 years of boredom" - what can he mean? It can help to know that Cohen wrote this lyric not to sing for himself, using the title 'we' to keep the option, but for Jennifer Warnes who recorded it with guitarist Stevie Ray Vaughan on her 1986 Famous Blue Raincoat. Two years later, Cohen recorded it on his own album I'm Your Man.

This song, still with references to the divine, "signal in the heavens", "birthmark on my skin", "how many nights I prayed for this", engages/advances the music industry, a testimony to triumph and the world tour: "then we take Berlin".

We are still caught with Heidegger reading Rilke on the dangers of production, even the constant production of oneself as a market item: for sale, for whatever recompense, coin, fame, a name. Thus in a seemingly gnostic turn, prefaced by his standard claims for Nietzsche's 'completion of metaphysics', Heidegger interrupts his own reading to quote Rilke's musing in a letter of 1 March 1912 that "the world draws into itself; for things, too, 
do the same in their turn, by shifting their existence more and more over into the vibrations of money, and developing there for themselves a kind of spirituality, which even now already surpasses their palpable reality". (Rilke cited in Heidegger 1971, p. 113) In the age of technological reproducibility, both

the humanness of human beings and the thingness of things dissolve into the calculated market value of a market which not only spans the whole earth as a world market, but also, as the will to will, trades in the nature of Being and thus subjects all beings to the trade of a calculation that dominates most tenaciously in those areas where there is no need of numbers. (Heidegger 1971, pp. 114-15)

It is in the world of things beyond price, "where there is no need of numbers", that Heidegger here suggests is the greatest danger of "calculation".

Later, Adorno arguably makes a similar point:

Inexorably, the thought of money and all its attendant conflicts extends into the most tender erotic, the most sublime spiritual relationships. With the logic of coherence and the pathos of truth, cultural criticism could therefore demand that relationships be entirely reduced to their material origin, ruthlessly and openly formed according to the interests of the participants. (Adorno [1951] 1974, $\S 22$, p. 43)

In other words, offering a different reading of Hölderlin on finding one's own in the foreign, "culture" for Adorno "displays its character as advertising" (Ibid., §26, p. 47).

What follows is that popular culture, including all elements of pop music, including the 'new muzak' —'new age' and drone and ASMR — could for Adorno serve for decoding advertising. In the same way, Adorno argued that one could learn to understand the social recognition mechanism of the hit parade in music; the making of presidents is also the making of pandemics as of Lady Gaga but also Bowie, the Ramones, and the same Bob Dylan on whom the Jesuit, Richardson, would write with some enthusiasm, quite along with whoever's next. ${ }^{15}$ Heidegger makes a similar point but, as Derrida says, raises the tone, and now the gnostic claim seems not far off:

The wholesome and sound withdraws. The world becomes without healing, unholy. Not only does the holy, as the track to the godhead, thereby remain concealed, even the track to the holy, the hale and whole, seems to be effaced. (Heidegger 1971, p. 117)

In this sense, the culture industry gives what the academic culture industry also gives, and that is what is always and ever the same, again and again, to say this again in German "Reproduktion des Immergleichen". (Adorno [1951] 1974, p. 74) Thus as Adorno and Horkheimer say with respect to the production of the star as such, all stars are manufactured, even academic ones, or they are not stars, representing consumers as so many brands of "Pseudoindividualität" not unlike Anders' reproof of Heidegger's 'pseudo-concreteness'.

Is Cohen a poet in needful times? I say yes, mindful that he would barely count as such for Heidegger, just as Rilke barely counts as such. What barely counts is still not nothing, if what we heard in Hölderlin, all crystalline amor fati, consecrating his life, read backwards, just as Nietzsche tells us that we have to take a backward glance and still say yes, remember Kairos-Once I lived as gods live-underlined with blessing, affirmation that asks for just what was: Einmal: once, one time-like the gods-and does not ask for more-we do not find in Rilke in Heidegger's "What Are Poets For?".

Needing Hölderlin, Heidegger has Rilke, and in our dark times, we have Cohen.

Funding: This research received no external funding.

Conflicts of Interest: The author declares no conflict of interest. 


\section{Notes}

1 See for a starter the aptly subtitled collection ("Difficult Others") by Lapidot and Brumlik (2017) as well as, here as a development of earlier contributions, (Di Cesare 2018) in addition to (Trawny 2015) and not less and explicitly esoterically, (Wolfson 2019), among other books on the Black Notebooks and the scandal associated with Heidegger's legacy such as the broad collection edited by (Farin and Malpas 2016).

2 See fairly recently, e.g., (Gordon 2016) as well as (Macdonald and Ziarek 2008) and, very substantially, (Mörchen 1981) in addition to, because there were two, (Mörchen 1980) and see as well, with a striking book cover to match its striking title, (Alker 2007). See too my own essay (Babich 2021b).

3 There are a number of readings of Adorno and Hölderlin, including my own in (Babich 2006), pp. 110-116, but see, more recently, (Wildanger 2018), and on Adorno and new music (not Heidegger), see, as ever apt, (Subotnik 2011).

See, for one discussion articulated with specific reference to Heidegger's Abbau, (Dyndahl 2008).

In what follows, I cite (Cohen 1993a).

I discuss this in (Babich [2013] 2016), including further references to the many authors who also discuss this phenomenon.

Please see (Babich 2019b) and (Babich 2019a).

It is worth underscoring that the beauty (and perhaps the point) of Richardson's book is that it takes no energy to engage. It is like Queen quite as many people discovered/rediscovered the music after the 2018 film (about Freddie Mercury), Bohemian Rhapsody, the 'soundtrack', for much of what had been Heidegger scholarship. If the ascendancy of analytic reading styles has changed that, that is not to say that there is a new backdrop. In other words, Richardson's Heidegger was unobtrusive in a way that Dreyfus, which always insists on its trademark is not, ditto Wrathall, ditto Carman both of whom draw upon the analytic tradition as does Sheehan and many others.

9 See for a video version of my lecture in Rochester, including my eulogy but also foregrounding the sexism inherent in Heidegger's Daseinanalyse in his conversations with Medard Boss, including a cut of Cohen's "You Want It Darker", (Babich 2019a).

10 Johann Gottfried Herder, cited in (Heidegger 1971, p. 139).

11 Hölderlin, Bread and Wine, cited in (Heidegger 1971, p. 94).

12 Among other reflections, Elliot Wolfson contextualizes the literality of this both/and: "In a manner consonant with mystics who have the capacity to extend the boundary of tradition without breaking it, Cohen draws the logical conclusion: If God's light is truly in every word, then there is no difference between the holy and broken gesticulation". In (Wolfson 2006, p. 127).

13 The inspiration for the issue was all Debra Bergoffen; the range of articles: a joint effort with Debra, myself and Dave Allison.

14 See for a reading in a broader context that may miss the publisher's vernissage (at Random House for the publication of Cohen's poetry, Stranger Music, (Lebold 2014)). Lebold wants the koan. Cf., here, the second footnote to (Wolfson 2006, pp. 103-4) along with (Lebold 2021), the last somewhat surprisingly limited (given everything written on "Hallelujah", as just that 'everything' happens to be the theme of Lebold's essay).

15 "oder daß man mit ihnen einmal eine Illustrierte liest und ihnen zeigt, wie dabei mit ihnen unter Ausnutzung ihrer eigenen Triebbeürftigkeit Schlittengefahren wird; oder daß ein Musiklehrer, der einmal nicht aus der Jugendmusikbewegung kommt, Schlageranalysen macht und ihnen zeigt, warum ein Schlager oder warum auch meinetwegen ein Stück aus der Musikbewegung objektiv so unvergleichlich viel schlechter ist als ein Quartettsatz von Mozart oder Beethoven oder ein wirklich authentisches Stück der neuen Musik". The late Ernest McClain, who, like Taubes, knew Adorno, was a musicologist over-preoccupied (as I supposed) with the arithmetic of the Hebrew bible and its musical metaphors as he analysed these, and whom I consulted on The Hallelujah Effect, surprised me by suggesting that Cohen's "Hallelujah", a reflexive song about King David and his composition, his "secret chord" that "pleased the Lord," baffled and all and if subjected to an Adorno-style "Schlageranalyse", qua performed and qua composed, would be, as he argued: manipulative. I offer an account as to why this is so (this is the 'Hallelujah Effect') to explain why many would favor such a song and to explore the performances that got under one's skin, adding k.d. lang to the pantheon of singers who have achieved this by 'covering' Cohen's song, in addition to the beautiful Jeff Buckley not infrequently claimed as the one to cover when one covers "Hallelujah".

\section{References}

Adorno, Theodor. 1974. Minima Moralia. Translated by Edmund Jephcott. London: Verso. First published 1951.

Alker, Andrea Barbara. 2007. Das Andere im Selben. Subjectivitätskritik und Kunstphilosophie bei Heidegger und Adorno. Würzburg: Königshausen und Neumann.

Anders, Günther. 1965. Being without Time: On Beckett's Play Waiting for Godot. In Samuel Beckett: A Collection of Critical Essays. Edited by Martin Esslin. Englewood Cliffs: Prentice Hall, pp. 140-51. First published 1956.

Anders, Günther. 1948. On the Pseudo-Concreteness of Heidegger's Philosophy. Philosophy and Phenomenological Research 8: 337-38. Anders, Günther. 2017. Musikphilosophische Schriften. Texte und Dokumente. Edited by Reinhard Ellensohn. Munich: Beck.

Anderson, Paul Allen. 2015. Neo-Muzak and the Business of Mood. Critical Inquiry 41: 811-40. [CrossRef]

Babich, Babette. 2016. The Hallelujah Effect: Music, Performance Practice and Technology. London: Routledge. First published 2013.

Babich, Babette. 2006. Words in Blood, Like Flowers: Poetry and Philosophy, Music and Eros in Hölderlin, Nietzsche, and Heidegger. Albany: State University of New York Press. 
Babich, Babette. 2007-2008. Ad Jacob Taubes. In New Nietzsche Studies: Nietzsche and the Jews. Edited by Allison David B., Babich Babette and Bergoffen Debra B. New York: Department of Philosophy, Fordham University, vol. 7, Nos. 3 \& 4. pp. v-x.

Babich, Babette. 2014. Hallelujah and Atonement. In Leonard Cohen and Philosophy: Various Positions. Edited by Jason Holt. Chicago: Open Court, pp. 123-36.

Babich, Babette. 2017. Are They Good, Are They Bad? Double Hermeneutics and Citation in Philosophy, Asphodel and Alan Rickman, Bruno Latour and the 'Science Wars'. In Das Interpretative Universum. Edited by Paula Angelova, Andreev Jaassen and Emil Lessky. Würzburg: Königshausen \& Neumann, pp. 259-90.

Babich, Babette. 2019a. William J. Richardson, S.J. and the Spelling of Marilyn Monroe: On Truth, Science, and the 'Unfolding of Man' in Heidegger and Lacan. In Heidegger Circle, Proceedings of the 53rd Annual Meeting New Orleans, LA, USA, 23-25 October 2014. Edited/Convened by Scott M. Campbell. Rochester: Nazareth College, pp. 197-232.

Babich, Babette. 2019b. Heidegger and Lacan: On Science and Truth and the 'Unfolding of Man'. Available online: https://www. library.fordham.edu/digital/item/collection/BabBabich/id/37?fbclid=IwAR1UklWMT3CLXQGv5W9qOg2hDzaLU_x8oP5 mVCigAZytkKi01AToJuKyTVE (accessed on 28 June 2021).

Babich, Babette. 2021a. From Anders' Sexless Capuchin to Virilio's Chimeras. In Babich, Günther Anders' Philosophy of Technology. London: Bloomsbury.

Babich, Babette. 2021b. Überlegungen nach Heidegger. Reflexionen aus dem beschädigten Leben. In Heidegger Jahrbuch 13. Zur Hermeneutik der Schwarzen Hefte. Edited by Michael Medved and Holger Zaborowski. Freiburg im Briesgau: Alber.

Bergoffen, Debra. 2007-2008. Introduction: Nietzsche and the Jews. New Nietzsche Studies 7: 1-3. [CrossRef]

Bernasconi, Robert. 1995. 'I will Tell You Who You Are': Heidegger on Greco-German Destiny and Amerikanismus. In From Phenomenology to Thought, Errancy, and Desire. Essays in Honor of William J. Richardson, S.J.. Edited by Babette Babich. Dordrecht: Kluwer, pp. 303-313.

Carson, Anne. 1986. Eros, the Bittersweet. Princeton: Princeton University Press.

Charland, Maurice. 2015. Recognition in Blue. Philosophy E Rhetoric 48: 583-602.

Cohen, Leonard. 1993a. Stranger Music: Selected Poems and Songs. New York: Vintage.

Cohen, Leonard. 1993b. 'I Am the Little Jew Who Wrote the Bible"-A Conversation between Leonard Cohen and Arthur Kurzweil. November 23. Available online: https:/ / www.leonardcohenfiles.com/arthurkurzweil.pdf (accessed on 28 June 2021).

Critchley, Simon. 2014. Bowie. London: OR Books.

Di Cesare, Donatella. 2018. Heidegger and the Jews: The Black Notebooks. Translated by Murtha Baca. Oxford: Wiley.

Dyndahl, Petter. 2008. Music Education in the Sign of Deconstruction. Philosophy of Music Education Review 16: 124-44. [CrossRef]

Farin, Ingo, and Jeff Malpas. 2016. Reading the Black Notebooks. Cambridge: MIT Press.

Gordon, Peter. 2016. Adorno and Existence. Cambridge: Harvard University Press.

Heidegger, Martin. 2001. Being and Time. Translated by John Macquarrie, and Edward Robinson. Oxford: Blackwell. First published 1927.

Heidegger, Martin. 1959. Introduction to Metaphysics. Translated by Ralph Manheim. New Haven: Yale University Press, p. 152.

Heidegger, Martin. 1968. What Is Called Thinking. Translated by Fred D. Wieck, and J. Glenn Gray. New York: Harper.

Heidegger, Martin. 1971. What Are Poets For. In Poetry, Language, Thought. Translated by Albert Hofstadter. New York: Harper Colophon, pp. 89-142.

Heidegger, Martin. 1977. The Question Concerning Technology and Other Essays. Translated by William Lovitt. New York: Harper \& Row, pp. 3-35.

Lapidot, Elad, and Micha Brumlik. 2017. Heidegger and Jewish Thought: Difficult Others. Lanham: Rowman \& Littlefield.

Lebold, Christophe. 2014. I'm the little Jew who wrote the Bible. A Reconfiguration of the Devotional Poet for the Age of the Mass Media: Leonard Cohen's Holy Hoaxes. In Literature and Spirituality in the English-Speaking World. Edited by Kathie Birat and Brigitte Zaugg. Oxford/Bern: Peter Lang, pp. 133-46.

Lebold, Christophe. 2021. Hallelujah: Why Leonard Cohen's Dark Hymn Will Forever Escape Trumping. Popular Music and Society 44: 107-10. [CrossRef]

Macdonald, Iain, and Krzysztof Ziarek. 2008. Adorno and Heidegger: Philosophical Questions. Stanford: Stanford University Press.

Maier-Katkin, Daniel. 2010. Stranger from Abroad: Hannah Arendt, Martin Heidegger, Friendship and Forgiveness. New York: Norton.

Mörchen, Hermann. 1980. Macht und Herrschaft im Denken von Heidegger und Adorno. Stuttgart: Klett-Cotta.

Mörchen, Hermann. 1981. Adorno und Heidegger. Untersuchung einer philosophischen Kommunikationsverweigerung. Stuttgart: Klett-Cotta.

Pio, Frederik, and Oivind Varkoy. 2015. Philosophy of Music Education Challenged: Heideggerian Inspirations Music, Education and Personal Development. Frankfurt am Main: Springer.

Richardson, William J. 2003. Through Phenomenology to Thought. New York: Fordham University Press. First published 1963.

Richardson, William J. 2010. Towards an Ontology of Bob Dylan. Philosophy and Social Criticism 36: 763-75. [CrossRef]

Shapiro, Gary. 2014. The End of the World and Other Times in The Future. In Leonard Cohen and Philosophy: Various Positions. Edited by Jason Holt. Chicago: Open Court, pp. 39-51.

Subotnik, Rose Rosengard. 2011. The Unwritable in Full Pursuit of the Unreadable: Adorno's Philosophie der Neuen Musik in Translation. Music Analysis 30: 89-139. [CrossRef]

Taubes, Susan Anima. 1954. The Gnostic Foundations of Heidegger's Nihilism. The Journal of Religion XXXIV: 155-72. [CrossRef] 
The Guardian. 2016. Leonard Cohen: Giving Nobel to Bob Dylan Like 'Pinning Medal on Everest'. 14 Oct. Staff Writer. Available online: https: / www.theguardian.com/music/2016/oct/14/leonard-cohen-giving-nobel-to-bob-dylan-like-pinning-medalon-everest (accessed on 28 June 2021).

Trawny, Peter. 2015. Heidegger and the Myth of a Jewish World Conspiracy. Translated by Andrew Mitchell. Chicago: University of Chicago Press.

Wildanger, Geoffrey. 2018. Inheriting Hölderlin: Adorno, Parataxis. MLN 133: 585-603. [CrossRef]

Wolfson, Elliot R. 2006. New Jerusalem Glowing. Kabbalah: Journal for the Study of Jewish Mystical Texts 15: 103-53.

Wolfson, Elliot. 2019. Heidegger and Kabbalah: Hidden Gnosis and the Path of Poiēsis. Bloomington: Indiana University Press. 